\title{
An Analysis of the Environmental Vulnerability Index of a Small Island: Lipe Island, Kho Sarai Sub-District, Mueang District, Satun Province, Thailand
}

\author{
Nutsurang Pukkalanun ${ }^{1}$, Wasin Inkapatanakul ${ }^{1}$, Chucheep Piputsitee ${ }^{2} \&$ Kasem Chunkao $^{1}$ \\ ${ }^{1}$ Faculty of Environment, Kasetsart University, Bangkok, Thailand \\ ${ }^{2}$ Faculty of Economic, Kasetsart University, Bangkok, Thailand \\ Correspondence: Nutsurang Pukkalanun, Faculty of Environment, Kasetsart University, Bangkok 10900, \\ Thailand. E-mail: to_gae@hotmail.com
}

This research was financed by the King's Royally Initiated Laem Phak Bia Environmental Research and Development Project

Received: December 16, 2012 Accepted: January 10, $2013 \quad$ Online Published: January 21, 2013

doi:10.5539/mas.v7n2p33

URL: http://dx.doi.org/10.5539/mas.v7n2p33

\begin{abstract}
Thailand is located in South East Asia and is a popular tourist destination. It is rich in both natural resources and culture. There are 691 islands in Thailand, and more than 214 of these islands are used for tourism. Koh Lipe is very Small Island of approximately 2 square kilometers, located in Talutao National Park in the southern part of Thailand. This research aims to assess the sensitivity of the Island in terms of tourism development by using the Environmental Vulnerability Index, or EVI. The results showed that the EVI of Lipe Island is approximately 5.7, which represents a very high vulnerability score. Particularly, the REI, the level of risk to hazard, which measures influences on the environment within the island (e.g., loss of forestry, tourist accommodation, waste water and solid waste) was approximately 6.2, while the EDI, the natural resilience of the state based on its native characteristics, (e.g. water resources, protected area, marine protected area, and law enforcement), was approximately 5.7. This is also a very important indicator of the vulnerability of the Island. Thus, to reduce the overall vulnerability of the island, all indicators included in the REI and the EDI must become management priorities. Over time, this will increase the immunity of the island to of the impact of tourism development.
\end{abstract}

Keywords: environment vulnerability, small island, Thailand

\section{Statement of the Problem}

Thailand is located in South East Asia where highly potential of tourism destinations in both natural resources and culture. Moreover, tourism generates enormous income and creates economic activities, for instance, wage, employment and creates business enterprise such as hotel, transportation and tourist agency etc. However, there are some tourism activities still face the problems in term of management likes waste, garbage, water and air pollution which effect to natural degradation, especially, the Island where distance from the main land and difficult accessibility.

There are 691 islands in Thailand and more than 214 islands are used for tourism destinations (The King's Royally Initiated Laem Phak Bia Environmental Research and Development Project, 2009). The utilization of natural resources for tourism destinations without any evaluates the potential of island in order to generate tourism activities; this will produce the problem in economics, environmental and social aspects. Furthermore, an island is also in the ecology fragile system (The King's Royally Initiated Laem Phak Bia Environmental Research and Development Project, 2009), therefore, tourist activity might harmful for island structure and this will change function of the island which is hard to recovery.

Koh Lipe or Lipe Island is located in Satun province, Southern part of Thailand. In the last few years, Koh Lipe has been grown rapidly in tourism sector. Unfortunately, the consequence of dramatic developing in small Island generate both social and environment problems for instance local people loss of their land as well as huge of wastes and garbage from tourist sectors on the island. Therefore, this research aims to identify the sensitive area 
particularly a small island by using environmental vulnerability index (EVI). To evaluate the island vulnerability in order to awareness that activity which takes place on the island might cause the environment degradation.

\section{Materials and Method}

\subsection{Study Area}

Lipe Island is Located in Talutao national park, Andaman sea, Southern part of Thailand. It is approximately 2 kilometer square and distance from main land, Satun province, about 70 kilometer. The characteristic of Lipe similar to $\mathrm{J}$ or upside down L. There are 187 households and the population is about 983 which are divided to men and men equally. Before Lipe Island become an attractive place of tourist destination, almost of men in the village are fishermen and women are housewife. In high season of tourism, some of fishermen work as a transfer boat from speech boat to each resort and this activity become local career.

Lipe Island is not connected beach to each other. There are 3 mains beach on the Island, Bandaya, sunrise and sun set beach. Because of monsoons from the Andaman sea, Lipe Island has only operate its tourism industry 6 months out of the year, from November to April.

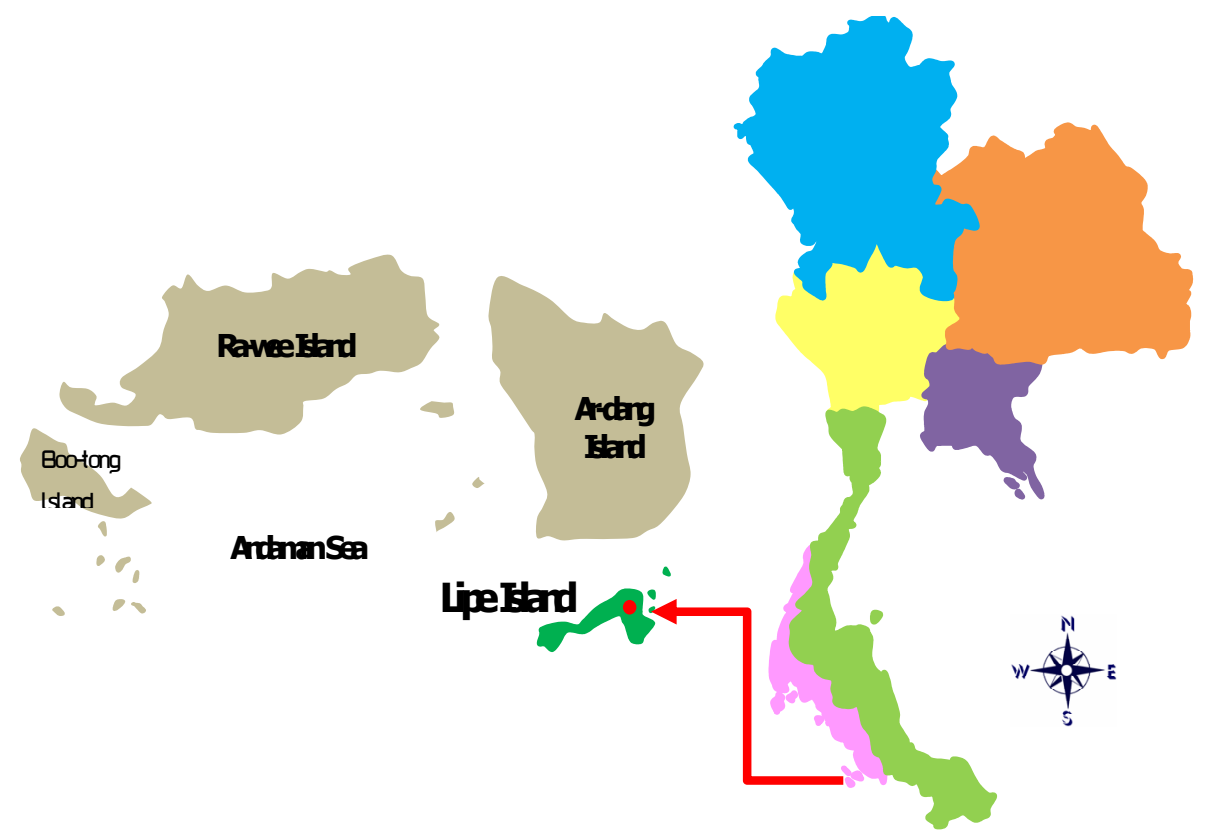

Figure 1. The location of Lipe Island

\subsection{Method}

In the past, the development of vulnerability indices focused on economic and social aspects which related to human dimensions. It has been clearly seen that environmental aspect was different from vulnerability of human systems because environment system is more complicated in ecological system (Kaly, 2000; Gowrie, 2003; Jens et al., 2006). However, in 1999, the Environmental Vulnerability Index (EVI) for Small Island developing States (SIDS) was developed by South Pacific Applied Geoscience Commission (SOPAC) which funded by New Zealand government. This was an initiative attempt to create environmental index and 54 indicators were built which three aspects of environmental vulnerability index were constructed. In this research, 18 indicators were used to measure the vulnerability of Lipe Islan as follow:

1) The Intrinsic Resilience sub-Index (IRI) that measures of natural resilience

$$
I R I=\frac{S c_{1} W t_{1}+S c_{2} W t_{2}+\ldots \ldots+S c_{4} W t_{4}}{W t_{1}+W t_{2}+\ldots \ldots \ldots . . W t_{4}}
$$

2) The Environmental Degradation Sub-Index (EDI) which evaluates the degree of damage

$$
E D I=\frac{S c_{5} W t_{5}+S c_{6} W t_{6}+\ldots \ldots+S c_{9} W t_{9}}{W t_{5}+W t_{6}+\ldots \ldots \ldots . . W t_{9}}
$$


3) The risk Exposure sub-index (REI) that illustrated the level of the risk natural hazard and human activities which the formula is as follow:

$$
R E I=\frac{S c_{10} W t_{10}+S c_{11} W t_{11}+\ldots \ldots .+S c_{18} W t_{18}}{W t_{10}+W t_{11}+\ldots \ldots \ldots . . W t_{18}}
$$

4) The Environmental Vulnerability Index (EVI) which identifies

$$
E V I=\frac{S c_{1} W t_{1}+S c_{2} W t_{2}+\ldots \ldots .+S c_{18} W t_{18}}{W t_{1}+W t_{2}+\ldots \ldots \ldots . . W t_{18}}
$$

Where

$$
\begin{aligned}
& \mathrm{Sc}=\text { Scoring } \\
& \mathrm{Wt}=\text { Weighting }
\end{aligned}
$$

Scoring is the standard universal number of each index which represents the level of Environmental vulnerability from 1-7 (less to more) (see Kaly, 1999)

Weighting is identified by the scholar who works in LipeIsland more than 10 year which rank from 1-3 (less to more) to illustrate of the important of each index in Lipe island.

From the calculating of environmental vulnerability index, the result of calculating can be identified the ranking of vulnerability of small island and the efficiency of environmental management which showed the table as follow:

Table 1. The result of calculating and evaluating of IRI, EDI, REI and EVI

\begin{tabular}{clll}
\hline \multirow{2}{*}{ Index } & \multicolumn{3}{c}{ Ranking } \\
\cline { 2 - 4 } & \multicolumn{1}{c}{$0-2.00$} & \multicolumn{1}{c}{ 2.01-4.00 } & \multicolumn{1}{c}{$4.01-7.00$} \\
\hline IRI & $\begin{array}{l}\text { Low natural and } \\
\text { manmade resilience }\end{array}$ & $\begin{array}{l}\text { Medium natural and } \\
\text { manmade resilience }\end{array}$ & $\begin{array}{l}\text { High natural and } \\
\text { manmade resilience }\end{array}$ \\
& High resistance and low & Medium resistance and \\
EDI & medium degradation & Low resistance and high \\
& Low of risk exposure & Medium of risk exposure & High of risk exposure \\
REI & Low Environmental & Medium Environmental & High Environmental \\
EVI & Vulnerability & Vulnerability & Vulnerability \\
\hline
\end{tabular}

Source: Coastal Habitats and Resources Management: CHARM 2007

\section{Results and Discussion}

Koh Lipe is very SmallIsland and approximately 2 square kilometer. It is located in Talutoa national park in the south of Thailand. The rapid development of Koh lipe particularly tourism sector generates environment problem such as solid waste, water pollution and environmental degradation. This research identify Koh Lipe island is a sensitive area which is fragile ecosystem. 18 indicators of environmental vulnerability index were represented the vulnerability of Koh Lipe which divided into 3 categories, the Intrinsic Resilience sub-Index (IRI), the Risk Exposure sub-index (REI), and the Environmental Degradation Sub-Index (EDI). The Intrinsic Resilience sub-Index (IRI) consists of land area, Low land, Habitats diversity and Relief and most of indicators are related the physical of the island which means the natural resilience of the state based on its native characteristics. While the Environmental Degradation Sub-Index (EDI) is fisheries, water resource, protected area, marine protected area and law enforcement and almost of indicators are about the level of risk to hazard which influence to the environment within the island. Likewise, Risk Exposure sub-Index (REI) is dry period, wet period, tsunami, population density, loss of forestry, tourism accommodation, source of tourism, waste water, solid waste which incorporates measures of the level of risk to hazard. The result of calculating the vulnerability of Koh Lipe has been shown in the Table 2 . 
Table 2. The result of calculating the REI, IRI, EDI and EVI of Koh Lipe

\begin{tabular}{|c|c|c|c|c|c|c|c|}
\hline No. & Index & $\begin{array}{l}\text { Weighting } \\
(\mathrm{W})\end{array}$ & Factors & Detail & $\begin{array}{l}\text { Raw } \\
\text { score }\end{array}$ & $\begin{array}{l}\text { Scoring } \\
\text { (S) }\end{array}$ & $\mathbf{W x S}$ \\
\hline 1. & IRI & 3 & Land area & Total land area (sq km) & 1.902 & 7 & 21 \\
\hline 2. & IRI & 2 & Relief & $\begin{array}{l}\text { Altitude range (highest point } \\
\text { subtract the lowest point in the } \\
\text { Island) }\end{array}$ & 110 & 7 & 14 \\
\hline 3. & IRI & 2 & Lowlands & $\begin{array}{l}\text { Percent of land area less than } 10 \\
\text { meters above sea level }\end{array}$ & 80 & 7 & 14 \\
\hline \multirow[t]{2}{*}{4.} & IRI & 3 & $\begin{array}{l}\text { Habitats } \\
\text { diversity }\end{array}$ & $\begin{array}{l}\text { The variety of coral leafs } \\
\text { mangroves, and seagrass }\end{array}$ & 1 & 1 & 3 \\
\hline & & 10 & & $\mathrm{IRI}=5.2$ & & & 52 \\
\hline 5. & EDI & 3 & Fisheries & $\begin{array}{l}\text { The number of fishing boats less } \\
\text { than } 10 \text { meters }\end{array}$ & $\leq 500$ & 1 & 3 \\
\hline 6. & EDI & 3 & $\begin{array}{l}\text { Water } \\
\text { resource }\end{array}$ & $\begin{array}{l}\text { Mean percentage of water usage } \\
\text { per year (surface water and } \\
\text { underground water) }\end{array}$ & & 7 & 21 \\
\hline 7. & EDI & 2 & $\begin{array}{l}\text { Protected } \\
\text { area }\end{array}$ & $\begin{array}{l}\text { Percentage of protected area on } \\
\text { the Island }\end{array}$ & $\leq 20$ & 7 & 14 \\
\hline 8. & EDI & 3 & $\begin{array}{l}\text { Marine } \\
\text { protected area }\end{array}$ & $\begin{array}{l}\text { Percentage of marine protected } \\
\text { area surrounding the Island }\end{array}$ & $\leq 20$ & 7 & 21 \\
\hline \multirow[t]{2}{*}{9.} & EDI & 3 & $\begin{array}{l}\text { Law } \\
\text { enforcement }\end{array}$ & $\begin{array}{l}\text { The enforcement or management } \\
\text { of environmental issues }\end{array}$ & non & 7 & 21 \\
\hline & & 14 & & $\mathbf{E D I}=\mathbf{5 . 7}$ & & & 80 \\
\hline 10. & REI & 1 & Dry period & $\begin{array}{l}\text { Number of months over the last } \\
\text { five years during which rainfall } \\
\text { is greatest than } 20 \text { percent lower } \\
\text { than the } 30 \text { year average. }\end{array}$ & 10 & 2 & 2 \\
\hline 11. & REI & 2 & Wet period & $\begin{array}{l}\text { Number of months over the last } \\
\text { five years during which rainfall } \\
\text { was greatest than } 20 \text { percent } \\
\text { higher than the } 30 \text { year average. }\end{array}$ & 50 & 7 & 14 \\
\hline 12. & REI & 1 & Tsunamis & $\begin{array}{l}\text { Percentage of risky of tsunamis } \\
\text { occurs on the island }\end{array}$ & $\leq 20$ & 1 & 1 \\
\hline 13. & REI & 1 & $\begin{array}{l}\text { Population } \\
\text { density }\end{array}$ & $\begin{array}{l}\text { Total human population density } \\
\text { (number per square kilometer } \\
\text { land area) }\end{array}$ & 20 & 1 & 1 \\
\hline 14. & REI & 3 & $\begin{array}{l}\text { Loss of } \\
\text { forestry }\end{array}$ & $\begin{array}{l}\text { Percentage of land area change } \\
\text { by removal of forest over the last } \\
5 \text { years }\end{array}$ & $>60$ & 7 & 21 \\
\hline 15. & REI & 3 & $\begin{array}{l}\text { Tourist } \\
\text { accommodati } \\
\text { on }\end{array}$ & Number of rooms (for tourists) & $>1,100$ & 7 & 21 \\
\hline 16. & REI & 3 & $\begin{array}{l}\text { Sources of } \\
\text { tourism }\end{array}$ & $\begin{array}{l}\text { Potential of source of tourism } \\
\text { evaluated by Tourism Authority } \\
\text { of Thailand }\end{array}$ & $>50$ & 7 & 21 \\
\hline 17. & REI & 3 & Waste water & $\begin{array}{l}\text { Ratio of waste water from } \\
\text { industries and communities }\end{array}$ & $>7,000$ & 7 & 21 \\
\hline \multirow[t]{3}{*}{18.} & REI & 3 & Solid waste & $\begin{array}{l}\text { The average amount of solid } \\
\text { waste per year }\end{array}$ & $>120$ & 7 & 21 \\
\hline & & 20 & & $\mathrm{REI}=6.2$ & & & 123 \\
\hline & & & & $\mathrm{EVI}=5.7$ & & & \\
\hline
\end{tabular}




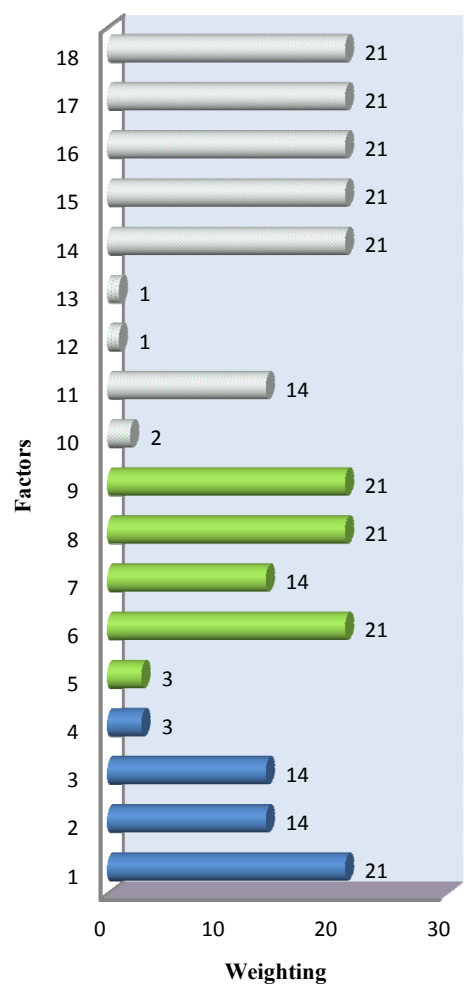

Lipe Island

Environmental Vulnerability Index (EVI):5.7

Total Index: 18

The risk Exposure sub-index (REI): 6.2

Total REI index: 9

The Intrinsic Resilience sub-Index (IRI): 5.2

Total IRI index: 4

The Environmental Degradation Sub-Index (EDI): 5.7

Total EDI index: 5

Symbol

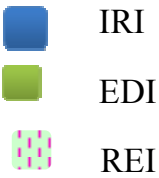

Figure 2. The scoring of IRI, EDI, REI and EVI of Lipe Island

From the Figure 2, it has been clearly seen that Lipe Island was extremely vulnerable area by calculating of EVI at 5.7. The result has shown that the Intrinsic Resilience Index (IRI) which consist of 4 factors, land area, relief, low land and habitats diversity, was 5.2. It was identified that this intrinsic Resilience of the island was highly vulnerability. Almost of factors are physical aspects therefore, to protect the island should consider the human activity which is not harmful for environmental degradation. Today Lipe is attractive tourist destination and welcome tourist all around the world, to generate tourism activity should appropriate to the function of the island Moreover, the Environmental Degradation Index (EDI) has illustrated the ability of natural resistance from natural disaster in the future. The factors were fisheries, water resource, protected area, marine protected and law enforcement. The result of EDI was about 5.7 and almost of factors related to activities was taking place on the island. Thus, to enhance the ability of natural resistance was to manage the activity in the island such as increase the protected area in both marine and on the island. Furthermore, small island of Lipe need restrict law enforcement to against illegal activities like water treatment and fishery. Moreover, the highest score of vulnerability of Lipe Island was 6.2, which was about Risk Exposure Index: REI. It contained of dry period, wet period, tsunami, and population density, loss of forest, tourism accommodation, and source of tourism, waste water, and solid waste. The factors emphasize on the impact of both natural condition and human activities. Some of factors of the risk exposure index were related to human activities like tourism destination. The number of tourist accommodation, waste water and solid waste were harmful for ecological system of Small Island. It would be generated the following problem and still exist in the island for instance, overuse of natural resources, deforestation, and water pollution etc. Almost of the scoring to identify the vulnerability was about 7 . To adjust the score to other ranking means factors need to be well management and the responsibility of all stakeholders who get the benefit from island should concern the activities taking place on the island.

\section{Conclusion}

It can be clearly seen that Lipe Island is vulnerable area. From the result of EVI has shown that 3 Indices and 18 factors represent the vulnerability of the island and about 13 factors reach the score about 7 . Some of factors cannot adjust the scoring because it contains of physical aspects. However, some of factors need to be well management like water resource, law enforcement, protected area, loss of forestation, tourist accommodation, waste water and solid waste. To generate immune and reduce the vulnerability for the island and reach the sustainable development, all of factors must restrict implementation. However, the limitation of EVI evaluation 
is not include social dimension, thus for the next research should focus on the impact of island development into the local or community who live on the Island.

\section{References}

Coastal Habitats and Resources Management. (2005). Vulnerability Mapping and Quality Status of Phang Nga and Ban Don Bay in Southern Thailand Project. Vilailuck University, Thailand

Coastal Habitats and Resources Management: CHARM. (2007). Ban Don Bay and its offshore Island Management planning Project: Analysis and Diagnosis of the Coastal Production Systems. Vilailuck University, Thailand

Jens, K., Grete, S., \& Lars, E. (2006). Assessing environment vulnerability in EIA-The content and context of the Vulnerability concept in an alternative approach to standard EIA procedure. Environmental Impact Assessment Review, 26, 511-527. http://dx.doi.org/10.1016/j.eiar.2006.01.003

Kaly, U. L., Briguglio, L., McLeod, H., Schmall, S., Pratt, C., \& Pal, R. (1999). Environmental Vulnerability Index (EVI) to summarize national environmental vulnerability profile. SOPAC Technical Report 275. Retrieved from http://www.sopac.int/data/virlib/TR/TR0275.pdf

Kaly, U. L., \& Pratt, C. (2000). Environmental Vulnerability Index: development and provisional indices for Fiji, Samoa, Tuvalu, and Vanuatu. SOPAC Technical Report 306. Retrieved from http://www.unescap.org/STAT/envstat/stwes-evi.pdf

Marissa, N. G. (2003). Environmental Vulnerability Index for the Island of Tobago, West Indies. Conservation Ecology, 7(2), 11. Retrieved from http://www.consecol.org/vol7/iss2/art11

The King's Royally Initiated Laem Phak Bia Environmental Research and Development Project. (2009). The report of Environmental quality on Lipe Island. Kasetsart university, Bangkok.

The Southern Study Limited. (2009). The final report of solid waste and waste water management in Lipe Island. Resources and Environment office, Satun province. Thailand. 